\title{
The Effect of Bank Deregulation on Bank Performance in Nigeria
}

\section{Olokoyo Felicia Omowunmi*}

\author{
Department of Banking \& Finance, College of Development Studies, Covenant University, Nigeria.
}

\author{
*Corresponding Author:Email:felicitymy79@gmail.com
}

\begin{abstract}
Privatization and Deregulation is a reality in Nigeria today as a direct result of successive thrusts from the private sector which in turn has influenced government policy of deregulating major sectors of the economy over the years. Among the institutions deregulated, is the banking industry in Nigeria.This study investigates the effects of bank deregulation on bank performance in Nigeria. The objective of this study is to analyze the areas that have been deregulated in the banking sector and how it has affected bank performance. To realize these objectives, the study analyzed secondary data collected from CBN statistical bulletin by employing the Ordinary Least Square (OLS) technique. This study found out that the deregulation of the banking sector has positive and significant effect on bank performance. It was recommended that bank management should embark on effective intermediation drive that will bring all the small savers to the purview of the banks, banks should improve their total asset turnover and diversify in such a way that they can generate more income on their assets and adequate efforts should be made by banks to increase their level of investments as that will help in generating reasonable returns on their assets. Also, the banking sector regulatory authorities have a duty to perform in ensuring that good corporate governance and the best of banking practices are obtainable in the nation's banking industry.
\end{abstract}

\section{Keywords: Banking industry, Deregulation, Intermediation, Privatization, Performance.}

\section{Introduction}

In literature public policy paradigm on banking regulation has shifted from economic regulation to deregulation to deregulation and prudential reregulation. On one hand the economic justification of financial deregulation is based on the presumption that deregulation fosters bank competition, which in turn may engender bank productive efficiency. Bank competition is seen as a stimulus to exert downward pressure on costs, reduce managerial slacks and even incentivize innovation [1]. On the other hand, concern about the adverse impact of increased competition on bank risk taking behaviour has motivated the adoption of prudential re-regulation alongside deregulation. Although prudential re-regulation is designed to mitigate excessive risk taking and foster stability, it may impose higher regulatory costs and hamper competition. Therefore, such a mixed process of deregulation and prudential reregulation may have opposite effects on bank performance.

It is curious that there is hardly any clear-cut evidence on what in theory, are opposite effects of policy reforms on these key aspects of bank performance. That is to say that the evidence is inconclusive. The deregulation described as the period of deregulation ended up with so many regulations aimed at correcting the distortions caused by regulatory controls. This is understandable because in order to change the old " rules of the game " new ones have to be put in place and this requires new regulations. The period generally referred to as the SAP period in Nigeria was designed to alter the structure and operational mechanism of the financial system among other objectives. The foreign exchange market and interest rate structure became important targets. In 1982 the country returned to stricter exchange control practices as a budgetary instrument to limit the country's foreign exchange expenditure, in line with the declining foreign exchange earnings worsened by the civil war. The foreign exchange control measures were complemented by the various trade restrictions and by 1983 there were as many as 182 commodities added to the lists of imports requiring licenses [2]. While there have been claims that Nigerian banks have performed better since deregulation, some others have maintained that this applies only to private rather than public banks, the call for government divestment in the interest of Nigerian banks has been made in line with the policy thrust of SAP.From another perspective, it has been argued that continued government involvement in the ownership and operations of 
banks, especially the larger ones (which by their age account for about $40 \%$ of the total assets of all banks), hindered their effective supervision thereby increasing the risk of failure and erosion of public confidence in the banking system. Hence, bank performance, its determinants and trends over the transition from a regulated to a deregulated economy, as well as the demands the transition makes on the supervisory authorities, requires greater attention. More than ever before, the preparedness and ability of the CBN to effectively supervise and conduct monetary policy in the resultant unprecedented expansion form the thrust of this study. This paper has five sections. Following this introductory part are literature review and model specification and estimation techniques in Sections 2 and 3 respectively. Section 4 covers the result from the estimation process and discussion, while in Section 5 is the conclusion.

\section{Literature Review}

The financial system is described as the gaunt of financial instrument, financial institutions and financial markets [3]. Due to the central position and the crucial role play by the financial sector, economists have provided evidence to show that there is growth and development of the economy. The financial sector in the opinion of experts can assist in breaking away from a depressed economic performance to an accelerated growth and performance. This is true if and only if the sector is not repressed and distorted with inappropriate and inflexible regulations. In any economy, there are two extreme policies which government can adopt in the process of achieving the goals and objectives of the nation. On one hand, the government can adapt the policy of directly controlling and guiding the economy towards the desired path of growth. In this case the policy is regarded as policy of regulation. On the other hand, the government can allow the market the market forces (that is, demand and supply) to freely determine the path of growth of the economy. Here the policy is known as the policy of deregulation [4].

Financial sector deregulation mainly involved the removal of interest and exchange rate control by the government and liberalization of bank licensing. According to Nwankwo [5], it is the deliberate and systematic removal of the regulatory control, structures and operational guidelines which may be considered inhibitive of orderly growth, competition and efficient allocation of resources in the financial system. It is not the complete removal of government control but the removal of some and strengthening others. Interest rates are the rental payments for the use of credit by borrowers and return for painting with liquidity by lender and depositors. These are categorized as lending rate and deposit rates respectively. Like other prices, interest rates perform a rationing function by allocating limited supply of credit among the many competing demands for it. According to Nwankwo [5] interest rate regulates the flow of business and industrial behaviour in any economy by influencing the supply of and demand for loan able fund. A major strategy of the programme is to deregulate the financial sector. According to Mckinnon [6], interest rate deregulation is the establishment of interest rate that equates the demand for supply of saving. They believe that financial sector deregulation is a prerequisite economic reform for economic development. This is because it encourages savings, investment innovations, adoption of technology and income equalization.

Foreign exchange rate is the price of one currency expressed in terms of another currency. In a deregulated foreign exchange market, the exchange rate is determined by the demand and supply of foreign currency. For example, if supply of foreign currency increases (because of increase in export income or capital inflow) in Nigeria, there will be sellers who cannot bid at the prevailing exchange rate. They will bid the price down (that is, the main will appreciate) until the required demand is forth coming. Government usually adopts the policy of deregulation in order to remove complex administrative control on economic activities. This is achieved by removing its direct involvement in many economic activities and by encouraging greater private sector participation and increased reliance on market for allocation of economic resources .These among other things formed the introduction of the structural adjustment programme in Nigeria in July 1986 [7].

\section{Development from the Deregulation of Bank and Other Reforms}

According to [2] with the adoption of SAP the regulatory framework guiding the operations of banks changed. Steps were taken to liberalize interest and lending rates. Many more banks were allowed entry into the sector. Competition increased a great deal among banks and the face of the industry changed within a few years. At different times ceilings on interest rates were removed, replaced and then removed again. In 1994, the ceilings and floors on interest rates were 
again restored. Regulatory authorities took steps to correct some of the endemic afflictions of banks that were carrying poor quality assets and had little cushion for it. Capital adequacy, liquidity and credit restrictions were enhanced to forestall the possibility of continuous deterioration in the health of the critically affected banks. Meanwhile, the newer banks developed new products and created various opportunities for exploiting profit. They grew in profits by leaps and bounds, though industry watchers claim the bulk of their profits is accounted for by their undue emphasis on foreign exchange trade and the sharp practices in which they engaged. This coupled with the continued depreciation of the naira since the inception of SFEM has led to a seemingly unending search for the ideal market mechanism for allocating scarce foreign exchange.

Banking reforms have been an ongoing phenomenon in the world right from 1980s, but has been more intensified in recent time because of the impact of globalization which is precipitated by continuous integration of the world market and economies. Banking reforms involve several elements that are unique to each country based on historical, economic and institutional imperatives. In Nigeria, the reforms in the banking sector preceded against the backdrop of banking crisis due to highly undercapitalization deposit taking banks; weakness in regulatory and supervisory framework; weak management practices; and the tolerance of deficiencies in the corporate governance behaviour of banks [8]. Banking sector reforms and recapitalization have resulted from deliberate policy response to correct perceived or impending banking sector crises and subsequent failures. A banking crisis can be triggered by weakness in banking system characterized by persistent illiquidity, insolvency, undercapitalization, high level of non-performing loans and weak corporate governance among others. Similarly, highly open economies like Nigeria, with weak financial infrastructure, can be vulnerable to banking crises emanating from other countries through infectivity. Banking crisis usually starts with inability of the bank to meet its financial obligations to its stakeholders. This, in most cases, precipitates runs on banks, the banks and their customers engage in massive credit recalls and withdrawals which sometimes necessitate Central Bank liquidity support to the affected banks. Some terminal intervention mechanisms may occur in the form of consolidation (mergers and acquisitions), recapitalization, use of bridge banks, establishment of asset management companies to assume control and recovery of bank assets, and outright liquidation of non redeemable banks. Bank consolidation, which is at the core of most banking system reform programmes, occurs, some of the time, independent of any banking crisis. Irrespective of the cause, however, bank consolidation is implemented to strengthen the banking system, embrace globalization, improve healthy competition, exploit economies of scale, adopt advanced technologies, raise efficiency and improve profitability. Ultimately, the goal is to strengthen the intermediation role of banks and to ensure that they are able to perform their developmental role of enhancing economic growth, which subsequently leads to improved overall economic performance and societal welfare. The proponents of Bank consolidation believe that increased size could potentially increase bank returns, through revenue and cost efficiency gains. It may also, reduce industry risks through the elimination of weak banks and create better diversification opportunities [9]. On the other hand, the opponents argue that consolidation could increase banks' propensity toward risk taking through increases in leverage and off balance sheet operations. In addition, scale economies are not unlimited as larger entities are usually more complex and costly to manage [10].

According to Adegbaju and Olokoyo [11], banking sector reforms in Nigeria are driven by the need to deepen the financial sector and reposition the Nigeria economy for growth; to become integrated into the global financial structural design and evolve a banking sector that is consistent with regional integration requirements and international best practices. It also aimed at addressing issues such as governance, risk management and operational inefficiencies and at the centre of the reforms is about firming up capitalization [12]. The reforms are designed to enable the banking system develop the required flexibility to support the economic development of the nation by efficiently performing its functions as the pivot of financial intermediation [13]. Thus, the reforms were to ensure a diversified, strong and reliable banking industry where there is safety of depositors' money and position banks to play active developmental roles in the Nigerian economy. Literature has shown that regulation and deregulation of the banking sector can have positive effect on bank performance provided the regulators and the operators are determined in their operation to make them work. There are two sides to this issue; some scholars opine that deregulation has positive effects while some find 
it detrimental on performance of banks. There are cases where regulation and deregulation have achieved their objectives and also situations where they have failed

The important aim of monetary stability in Nigeria has not been attained after deregulation. Monetary growth was far in excess of targets and resulted in large exchange rate depreciation and persistent inflationary pressures; Federal Government deficit kept rising; interest rates and inflation kept rising an $d$ there was excess of targets and resulted in large exchange rate depreciation and persistent inflationary pressures; Federal Government fiscal deficit. Interbank rates climbed to an alarming rate which in turn affected other rates. Because the expected monetary stability failed to materialize, government resorted to issuing stabilization securities in 1990 and transferred government accounts from the banks to the CBN. On the other hand, the massive sets of regulations introduced several introductions as bank and other financial institution came out with several new products. These innovations have been largely responsible for the crashed financial institutions and banks. Some of the innovations which came with deregulation also turned out to be counterproductive. Hence, the need to answer the question as to whether deregulation affects bank performance positively or negatively [5, 1-16].

\section{Model Specification and Estimation Techniques}

The model for the paper assumes an underlying relationship between some macroeconomic variables that can influence the performance of banks measured by the commercial banks investments-to-total assets ratio (IAR) which is a measure of the banking industry performance and soundness. This is informed by the information gained from literature. The relevant explanatory variables used are money supply growth rate (M2R), maximum lending rate (MLR), liquidity ratio (LR), loan-to-deposit ratio (LDR) and monetary policy rate (MPR). To examine this, the paper employs the ordinary least squares single equation technique in the estimation procedure. As a justification for this method, Maddala [17] identified that ordinary lest square is more robust against specification errors than many of simultaneous equation methods. Also predictions from equation estimated by ordinary least squares often compare favourably with those obtained from equations estimated by the simultaneous equation method. Among other reasons is the simplicity of its computational procedure in conjunction with optimal properties of the estimates obtained and these properties are linearity, unbias and minimum variance among a class of unbiased estimators.

With regards to the merits ordinary least squares single equation modelling method; this paper represents a model below relating IAR to other explanatory variables:

$\mathrm{IAR}=\mathrm{f}(\mathrm{M} 2 \mathrm{R}, \mathrm{MLR}, \mathrm{LR}, \mathrm{LDR}, \mathrm{MPR}, \mathrm{U})$

The explicit form of Equation 1 and the coefficients' expected signs is represented as follows:

$\mathrm{IAR}=\mathrm{a}_{0}+\mathrm{\alpha}_{1} \mathrm{M} 2 \mathrm{R}+\mathrm{\alpha}_{2} \mathrm{MLR}+\mathrm{\alpha}_{3} \mathrm{LR}+\mathrm{\alpha}_{4} \mathrm{LDR}+$ $\mathrm{a}_{5} \mathrm{MPR}+\varepsilon$

where IAR is banks' investment to total assets ratio; M2R is money supply growth rate; MLR is maximum lending rate; $\mathrm{LR}$ is liquidity ratio; LDR is loan-to-deposit ratio; MPR is monetary policy rate; $\varepsilon$ is the error term; $\alpha_{0}$ is intercept; and $\alpha_{1,} \alpha_{2}$, $\alpha_{3}, \alpha_{4} \& \alpha_{5}$ are parameter estimates. The $a$ priori is such that $\alpha_{1}, \alpha_{3}, \alpha_{4}, \alpha_{5}>0$ and $\alpha_{2}<0$.

\section{Estimation and Discussion}

The paper employed the use of econometric tools in the analysis of the variables shown in the model. Annual time-series data on the variables under study covering twenty-five year period are used in this study for estimation of the model function. Data were sourced from the Central Bank of Nigeria (CBN) Statistical Bulletin for the period 1986 - 2010. The E-views package was used in the estimation process and results are presented in tables. The regression result is presented in table 4.1 below:

From the regressions results in table 4 , the $\mathrm{R}$ squared $\left(\mathrm{R}^{2}\right)$ value of 0.683 shows that at $68.3 \%$ the explanatory variables, money supply growth rate, maximum lending rate, liquidity ratio, loanto-deposit ratio and monetary policy rate jointly, explain changes in the dependent variable, investments-to-total banks assets ratio. This means that at $68.3 \%$ the independent variables explain changes in investments-to-total banks assets ratio, implying that the explanatory variables explain the behaviour of the dependent variable at $68.3 \%$. The calculated F-statistics of 6.126 implies that the model itself is statistically significant and the goodness of fit is moderately sound. The Durbin-Watson (DW) as shown in the regression analysis is 2.143 . It shows that there is no autocorrelation.

How far do the directions of the influences of the various explanatory variables conform to the a priori expectations expressed section three? This 
question is warranted since any reliable estimated regression equation is expected to conform to the priori restrictions imposed or determined by the theoretical underpinning of the study in question.

Table 1: Regression results

\begin{tabular}{lllllllll}
\hline Variable & Coeff & Std. Error & t-statistic & Prob & R-Squ. & $\begin{array}{l}\text { Adj. } \\
\text { squ. }\end{array}$ & $\begin{array}{l}\text { D.W } \\
\text { Stat. }\end{array}$ & F-stat \\
\hline C & -7.8089 & 2.772257 & -2.81683 & 0.0119 & & & & \\
M2R & 0.00749 & 0.011690 & 0.640706 & 0.5303 & & & & \\
MLR & 0.205395 & 0.06499 & $3.159971^{* * *}$ & 0.0057 & & & & \\
LR & 0.039991 & 0.027445 & 1.457113 & 0.1633 & 0.683 & 0.7821 & 6.1265 & 2.1434 \\
LDR & 0.076763 & 0.021465 & $3.576215^{* * *}$ & 0.0023 & & & & \\
MPR & -0.19223 & 0.079021 & $-2.43260^{* *}$ & 0.0263 & & & & \\
\hline
\end{tabular}

Note: *** Significant at 1\% level; ** Significant at $5 \%$ level and * Significant at $10 \%$ level. M2R = money supply growth rate; MLR $=$ maximum lending rate; $\mathrm{LR}=$ liquidity ratio; $\mathrm{LDR}=$ loan-to-deposit ratio; $\mathrm{MPR}=$ monetary policy rate; the ' $\mathrm{F}$-stat' is the ratio used in the statistical test of the significance of the model and 'DW' is the Durbin-Watson statistic used in the test of auto correlation.Source: Results obtained from data analysis using the E-Views statistical software package

From the results, it is interesting to note that most of the signs turned out as expected from the a-priori sign with the exception of MLR and MPR. A common cause of worry in empirical research is the appearance of 'wrongly' signed coefficients in regression models, that is, if specification or interpretation of the coefficient is correct, a coefficient can still attain a wrong sign because of the sampling distribution of the estimates. If this is the case, we generally observe the coefficients to be not statistically significantly different from zero. However, the 'wrong' sign in the maximum lending and monetary policy rate coefficients are not found to be connected with any error in the definition or interpretation of the model variables.

The result obtained from the regression shows that there is positive relationship between money supply growth rate and investments-to-total banks assets ratio with a coefficient of 0.011690 , this shows there is a positive relationship between money supply growth rate and investments to total banks assets. However, the respective standard error (0.011690), t-statistic (0.640) and probability (0.305) values reveals that the relationship is not statistically significant. The result shows a positive relationship between maximum lending rate and investments to total banks assets ratio with a coefficient of 0.2053 . The standard error (0.064), t-statistic (3.159) and probability $(0.0057)$ is highly significant at $1 \%$ level. Also, there is a positive relationship between liquidity ratio and investments-to-total banks assets ratio with a coefficient of 0.039. The respective standard error (0.0274), t-statistic (1.457) and probability (0.388) values is however not significant. The result obtained from the regression further shows that there is positive relationship between loan-to-deposit ratio and investments-to-total banks assets ratio with a coefficient of 0.076 . The respective standard error (0.021), t-statistic (3.576) and probability (0.007) values are significant at $1 \%$ level of significance. Finally, the regression result shows that there is negative relationship between monetary policy rate and investments to total banks assets ratio with a coefficient of -0.192 . The respective standard error (0.079), t-statistic (-2.432) and probability $(0.0263)$ values are significant at $5 \%$ level of significance. Hence we reject the null hypotheses $\left(\mathrm{H}_{0}\right)$ for MLR, LDR and MPR and conclude that both maximum lending rate and loan-to-deposit ratio have a highly significant positive effect on banks' performance while the monetary policy rate has a negative significant influence on banks' performance. We however accept the null hypotheses for M2R and LR and conclude that money supply growth rate and liquidity ratios do not have a significant influence on banks' performance. The overall empirical evidence suggests that there is a significant relationship between the regulation of banks and banks' performance and hence does not support the position that deregulation bring about improvement in banks performance.

\section{Conclusion}

In this study, an econometric study of deregulation in the banking sector and how it has affected the banking industry performance was undertaken using time series data for the period from 1986 to 2010 . It was found that only two out of the five bank regulation coefficients of are not statistically significant to banks' measure of performance (investments-to-total assets ratio) during the period under analysis, 1986-2010. Hence, the empirical results do not definitely support the positions that regulation of banks can lead to poor performance and consequently bank failure and that deregulation can lead to better corporate performance for banks in Nigeria. This paper is of the opinion that deregulation on its own does necessarily translate to better performance but when combined with other 
regulatory policies, banks stand a better chance of growth and survival. This paper therefore recommends that bank management should embark on effective intermediation drive that will bring all the small savers to the purview of the banks, CBN has said over time that most of the money in circulation is in the informal service sector which the banks have neglected over the years, bringing this fund through effective

\section{References}

1. Nickell S (1996) Competition and corporate performance, Journal of Political Economy, 5:34-9.

2. Akiode P, Sodobu O (1998) Bank supervision and deregulation in Nigeria; Analysing the transition into a deregulated economy, African Research Consortium 71:25-27.

3. Adams GA (2001) Deregulation of the Downstream Sector of the Petroleum Industry, Post Express Newspaper, May17, p 4.

4. Asediolen (2004) For the Economic and Financial Interest of Nigeria, Nigerworld:1 \& 2.

5. Nwankwo GO (1990) Prudential Regulation of Nigerian Banking, Unilag Press. Lagos.

6. McKinnon RI (1988) Financial Liberalization and Economic Development: A Reassessment of Interest Rate Policies in Asia and Latin America, ICEG Occasional Papers No.6.

7. Anyanwu CI (1987) Impact of Interest Rate Deregulation on the Nigerian Economy Business Concord, August 28.

8. Uchendu OA (2005) Banking Sector Reforms \& Bank Consolidation: The Malaysian Experience, Bullion . 29, (2).

9. Berger AN (2000) The Integration of the Financial Services Industry: Where Are the Efficiencies?" FEDS Paper, No. 2000:36.

10. De Nicolo, Gianni, et al. (2003) Bank Consolidation, Internationalization and intermediation drive will provide a cheap source of fund for the banks which they can use to generate more interest income which will eventually increase their returns. Moreso, the bank regulatory authority need to ensure that certain policy tools such as the money supply, liquidity ratio, maximum lending rate, monetary policy rate are effectively managed to enhance good corporate governance and better performance of the banking industry.

Conglomeration: Trends and Implications for Financial Risk, IMF Working Paper, 3, p158

11. Adegbaju AA, Olokoyo FO (2008) Recapitalization and bank's performance; A case study of Nigerian banks African Economic and Business Review, 6(1)1-4.

12. Ajayi M (2005) Banking sector reforms and bank consolidation; Conceptual framework, Bullion, 29(2).

13. Lemo $\mathrm{T}$ (2005) Regulatory Oversight and Stakeholder Protection, Paper Presented at the BGL Mergers and Acquisitions Interactive Seminar, held at Eko Hotels \& Suite,Lagos.

14. Soyibo A, Adekanye F (1992) The Nigerian banking systems in the context of policies of financial regulation and deregulation, African Economic Research Consortium Research 17:2123.

15. Ekpeyong DB (1993) The Financial Sector, in Adalemo I.A. J. (1993), Nigerian, Giant in Tropics, Gabumo Publishing Co. Ltd; Lagos

16. Ojo MO (1994) The Economics of Controls and Deregulation: The Nigerian Experience, CBN Research Department Occasional Paper No.10. pp 33-38

17. Maddala GS (1997), Econometrics, New York McGraw-Hill. 